\title{
Methods to Study PAMP-Triggered Immunity in Brassica Species
}

\author{
Simon R. Lloyd, ${ }^{1}$ Henk-jan Schoonbeek, ${ }^{1}$ Martin Trick, ${ }^{2}$ Cyril Zipfel, ${ }^{3}$ and Christopher J. Ridout ${ }^{1}$ \\ ${ }^{1}$ Crop Genetics Department and ${ }^{2}$ Computational and Systems Biology Department, John Innes Centre, Norwich Research \\ Park, Norwich, NR4 7UH, U.K.; ${ }^{3}$ The Sainsbury Laboratory, Norwich Research Park, Norwich, NR4 7UH, U.K.
}

Submitted 29 May 2013. Accepted 6 October 2013.

\begin{abstract}
The first layer of active defense in plants is based on the perception of pathogen-associated molecular patterns (PAMPs) leading to PAMP-triggered immunity (PTI). PTI is increasingly being investigated in crop plants, where it may have potential to provide durable disease resistance in the field. Limiting this work, however, is an absence of reliable bioassays to investigate PAMP responses in some species. Here, we present a series of methods to investigate PTI in Brassica napus. The assays allow measuring early responses such as the oxidative burst, mitogen-activated protein kinase phosphorylation, and PAMP-induced marker gene expression. Illumina-based RNA sequencing analysis produced a genome-wide survey of transcriptional changes upon PAMP treatment seen in both the $A$ and $C$ genomes of the allotetraploid $B$. napus. Later responses characterized include callose deposition and lignification at the cell wall, seedling growth inhibition, and PAMP-induced resistance to Pseudomonas syringae and Botrytis cinerea. Furthermore, using these assays, we demonstrated substantial variation in PAMP responses within a collection of diverse $B$. napus cultivars. The assays reported here could have widespread application in $B$. napus breeding and mapping programs to improve selection for broad-spectrum disease resistance.
\end{abstract}

Active plant defense comprises two levels of threat detection employed by the host. The first level involves recognition of pathogen-associated molecular patterns (PAMPs) or microbeassociated molecular patterns at the cell membrane by pattern recognition receptors (PRR) (Boller and Felix 2009; Dodds and Rathjen 2010). PAMPs are conserved molecules present in entire groups of microbes that are important for the normal life cycle of the organism (Medzhitov and Janeway 1997). The resulting PAMP-triggered immunity (PTI) downstream of the PRR comprises a series of defense reactions often sufficient to halt further pathogen growth. The second level of pathogen detection is defined as effector-triggered immunity (ETI), responses to specific effectors delivered by a host-adapted pathogen (Chisholm et al. 2006; Dodds and Rathjen 2010; Jones and Dangl 2006).

PAMP-PRR pairs have been identified in a growing number of different plant species (Monaghan and Zipfel 2012). All

Corresponding author: C. J. Ridout; E-mail: christopher.ridout@jic.ac.uk; Telephone: +44 (0) 1603450286.

* The $\boldsymbol{e}$-Xtra logo stands for "electronic extra" and indicates that five supplementary figures and two supplementary tables are published online.

(C) 2014 The American Phytopathological Society currently known plant PRR are either receptor-like kinases (RLK) or receptor-like proteins (RLP). The leucine-rich repeat (LRR)-RLK family XII includes the PRR flagellin sensitive 2 (FLS2) and elongation factor (EF)-Tu receptor (EFR) in Arabidopsis thaliana and $\mathrm{Xa} 21$ in rice. These PRR recognize the proteinaceous bacterial PAMPs flagellin (Felix et al. 1999; Gomez-Gomez and Boller 2000) and EF-Tu (Kunze et al. 2004; Zipfel et al. 2006) and the type-I secreted sulphated peptide Ax21, respectively (Lee et al. 2009; Song et al. 1995). FLS2 was first identified in A. thaliana (Gomez-Gomez and Boller 2000) but functional orthologs have been found since then in other species, with flagellin perception probably occurring in most higher plants (Albert et al. 2010; Boller and Felix 2009; Felix et al. 1999). Functional FLS2 orthologs have been identified in Nicotiana benthamiana (Hann and Rathjen 2007), tomato (Robatzek et al. 2007), and rice (Takai et al. 2008). In contrast to FLS2, the presence of EFR and Xa21 appear to be restricted to members of the family Brassicaceae and to rice, respectively (Boller and Felix 2009; Kunze et al. 2004; Lee et al. 2009; Schwessinger and Ronald 2012; Zipfel et al. 2006).

The first PRR identified as recognizing chitin, a $\beta$-1,4-linked polymer of $\mathrm{N}$-acetylglucosamine and essential constituent of the fungal and insect cells, was the lysin motif (LysM) containing the RLP chitin elicitor binding protein (CEBiP) in rice (Kaku et al. 2006). Another LysM-containing protein is chitin elicitor receptor-like kinase 1 (CERK1), first identified in $A$. thaliana (Miya et al. 2007; Wan et al. 2008). Although both CERK1 and CEBiP are widely distributed among plant species, AtCERK1 directly binds to chitin (Iizasa et al. 2010; Liu et al. 2012b; Petutschnig et al. 2010), whereas CEBiP is the chitin receptor in rice forming a ligand-induced complex with OsCERK1 (Shimizu et al. 2010). Notably, CEBiP-like RLP do not seem to contribute to chitin perception in A. thaliana (Shinya et al. 2012; Wan et al. 2012). Consistent with the potential existence of multi-protein receptor complexes, CERK1 has also been implicated in the recognition of the bacterial PAMP peptidoglycan in A. thaliana (Willmann et al. 2011). In rice, two additional LysM-RLP are important for both chitin and PGN recognition (Liu et al. 2012a). Another LysM-RLK, LYK4, has also been recently linked to chitin perception in A. thaliana (Wan et al. 2012). In tomato, the LRR-RLP ethylene-inducing xylanase receptor 2 is a receptor for xylanase from Trichoderma spp. (Ron and Avni 2004). Also in tomato, the LRR-RLP Ve1 recognizes Ave1 from multiple strains of Verticillium (de Jonge et al. 2012; Fradin et al. 2009).

Identification of novel PRR and understanding differences in PTI within diverse species has potential to be applied commercially. For example, the interfamily transfer of $A t E F R$ into tomato, which lacks a native $E F R$ homolog, conferred responsiveness to EF-Tu and increased broad-spectrum resistance to 
bacteria (Lacombe et al. 2010). Similarly, transgenic Citrus sinensis expressing Xa21 had higher resistance against multiple strains of Xanthomonas axonopodis (Mendes et al. 2010). These examples indicate that similar downstream signaling components are shared between structurally distinct PRR and highlight the potential benefit of using PRR in a transgenic approach to disease control.

Genome-wide association mapping identified six RLK colocalizing with quantitative trait loci for disease resistance to southern leaf blight (Cochliobolus heterostrophus) in maize, suggesting the potential involvement of uncharacterized PRR in that pathosystem (Kump et al. 2011). Molecular markers based on PTI-related genes could be used to test similar associations in other crops and potentially be used for selection in marker-assisted breeding.

Quantifying immune outputs downstream of PRR are the primary means for assessing PTI and PAMP responsiveness. Rapid mitogen-activated protein kinase (MAPK) phosphorylation, $\mathrm{Ca}^{2+}$ influx, and an oxidative burst are PTI responses that occur within min following PAMP perception (Boller and Felix 2009). These PTI responses have been demonstrated in species as diverse as grapevine (Dubreuil-Maurizi et al. 2010), barley (Proels et al. 2010), Brassica spp. (Dunning et al. 2007), tomato (Nguyen et al. 2010), and soybean (Valdés-López et al. 2011). Earlier examples of responses to chitin or chitosan have historically been shown in rice cell cultures, including measurement of plasma membrane ion fluxes, phytoalexin accumulation, and chitinase expression (Kishimoto et al. 2010; Kuchitsu et al. 1997; Nishizawa et al. 1999; Yamada et al. 1993). Substantial transcriptional changes occur rapidly upon PAMP treatment and specific marker genes can be used to quantify PAMP responsiveness (Navarro et al. 2004; Wan et al. 2008; Zipfel et al. 2004, 2006). Large-scale transcriptome analysis is a powerful method for identifying novel PAMP-responsive genes and has been carried out in A. thaliana, soybean, and rice (Akimoto-Tomiyama et al. 2003; Navarro et al. 2004; Zipfel et al. 2004; Valdes-López et al. 2011).

Callose deposition has also been used to evaluate PAMP responses. Callose deposits are matrices of polymeric $\beta$-(1-3)glucans that form distinct papillae between the cell membrane and cell wall. The cross-linking of $\beta$-glucans is catalyzed by callose synthases, of which PMR4 is known to play a key role in responses to PAMPs (Ham et al. 2007). Loss of callose deposition in A. thaliana correlated with increased growth of a nonadapted strain of Pseudomonas syringae, highlighting the importance of callose in antibacterial immunity (Ham et al. 2007). The role of callose deposition in resistance against important Brassica pathogens, such as Leptosphaeria maculans, $X$. campestris pv. campestris, and Sclerotinia sclerotium, is still largely unknown.

Lignification is a mechanism of cell wall reinforcement that occurs through the oxidative cross-linking of the monolignans into long-chain polymers of insoluble lignin (Vanholme et al. 2010). The lignin biosynthetic genes cinnamyl alcohol deydrogenase $\mathrm{C}$ and $\mathrm{G}$ (CAD-C and $-\mathrm{G}$, respectively) are upregulated during interactions with certain pathogens (Tronchet et al. 2010). Lignification during defense might be particularly relevant to research on the interactions between Brassica spp. and their pathogens because it has been proposed as one of the mechanisms of resistance acting within the stem and petiole against L. maculans (Huang et al. 2009).

An assay widely used for PAMP responsiveness is PAMPinduced resistance (PIR). The protective effect of PAMP treatment, or crude bacterial or fungal preparations, on subsequent pathogen growth has been demonstrated clearly in A. thaliana, where the application of flagellin or its derived peptide, flg22, reduced the subsequent growth of the bacterial pathogens $P$. syringae pv. tomato DC3000 (Zipfel et al. 2004) and X. campestris pv. campestris (Sun et al. 2006), the fungus Botrytis cinerea (Ferrari et al. 2007), and the oomycete Hyaloperonospora arabidopsidis (Fabro et al. 2011). In other plant species, flg22 has been shown to induce resistance to $P$. syringae pv. tomato DC3000 on tomato (Nguyen et al. 2010) and S. sclerotiorum on soybean (Valdés-López 2011). N-acetylchitooligosaccharides can induce resistance to Magnaporthe grisea on rice (Ning et al. 2004).

Brassica napus (oilseed rape or canola) is a good candidate for the transfer of fundamental research from A. thaliana; both species are members of the family Brassicaceae, there is a wealth of genetic and genomic resources available for Brassica crop improvement, and the oilseed crop is increasingly important worldwide (Fitt et al. 2008). The genera Arabidopsis and Brassica diverged from a common ancestor over 17 million years ago, and subsequent hybridization of diploid A ( $B$. rapa) and $C$ (B. oleracea) genomes produced the allotetraploid $B$. napus (Yang et al. 2006). There is a need to identify sources of durable and effective quantitative (or partial) resistance to common Brassica pathogens such as L. maculans (Aubertot et al. 2006), $X$. campestris, $P$. syringae, $S$. sclerotiorum, and $B$. cinerea. Although strain-specific resistance $(R)$ genes could provide extremely strong levels of disease control, this effectiveness can be rapidly lost as, for example, in the breakdown of Rlm1-mediated resistance within five years of deployment (Sprague et al. 2006). Conversely, lines with strong quantitative disease resistance have often been deployed for longer periods of time, such as in the European 'Jet Neuf', which was widely grown for over 20 years and is still used in breeding programs (Delourme et al. 2006). Developing the tools to identify potential sources of durable quantitative resistance has proven difficult, however.

Although limited work has been in done assaying natural variation in PAMP responses, assays such as the measurement of oxidative burst have been utilized to map key components of PTI within crop species (Valdés-López et al. 2011). Substantial variation exists in FLS2 abundance and specific binding capacity for flg22 between a range of different $A$. thaliana ecotypes and other species of the family Brassicaceae, and this variation has been shown to directly correlate with seedling growth inhibition by flg22 (Vetter et al. 2012). Furthermore, sequence analysis of $F L S 2$ within the family Brassicaceae revealed significantly higher differences in the LRR domain between Brassica spp. (56\% universal amino acid identify) than in all sequenced Arabidopsis ecotypes (98.8\% identity) (Dunning et al. 2007).

The extent of PTI's contribution to quantitative resistance as it is described in the field and the importance of PAMP responses in interactions between $B$. napus and its key pathogens is currently unknown. Our objective was to develop tools to investigate PTI within Brassica spp. and to assess their potential for use in selecting for resistance in varieties. We present a series of techniques to investigate PTI within B. napus 'Temple'. In addition, we investigated variability in these responses among multiple B. napus varieties. Our results form a basis for research into PTI in Brassica spp. and its potential application for improved disease control against its most devastating pathogens.

\section{RESULTS AND DISCUSSION}

In order to develop PAMP response assays in B. napus, we focused on first developing techniques for a single genotype and using well-characterized PAMPs (e.g., flg22, elf18, and chitin) of diverse microbial origin. Because responses triggered by different PAMPs are mostly congruent (Wan et al. 2008; Zipfel et 
al. 2006) and do not necessarily induce microbe-specific immunity (Ferrari et al. 2007; Zipfel et al. 2004), the toolbox developed using these PAMPs could be used in future studies to correlate the extent of PTI responsiveness to quantitative resistance to distinct pathogens. We chose the line Temple because it is the center of a large mapping experiment as part of the Oilseed Rape Genetic Improvement Network (OREGIN) project. Temple is the common parent in many diverse crosses and, with a large number of genetic resources developing around the line, it was an ideal candidate for our assay development.

\section{Early responses to PAMPs.}

One of the most characteristic PAMP responses studied is the oxidative burst: the rapid and transient accumulation of reactive oxygen species (ROS) within a few minutes of PAMP perception (Boller and Felix 2009). Using a luminol-based assay, we could show that $\mathrm{H}_{2} \mathrm{O}_{2}$ is produced within 5 to $10 \mathrm{~min}$ in response to flg22, elf18, and chitin (crab shell chitin [CSC]) in B. napus (Fig. 1A and B). Optimal concentrations for the assay were between 50 and $100 \mathrm{nM}$ for flg22 and elf18, with no significant increase in $\mathrm{H}_{2} \mathrm{O}_{2}$ production at higher concentrations
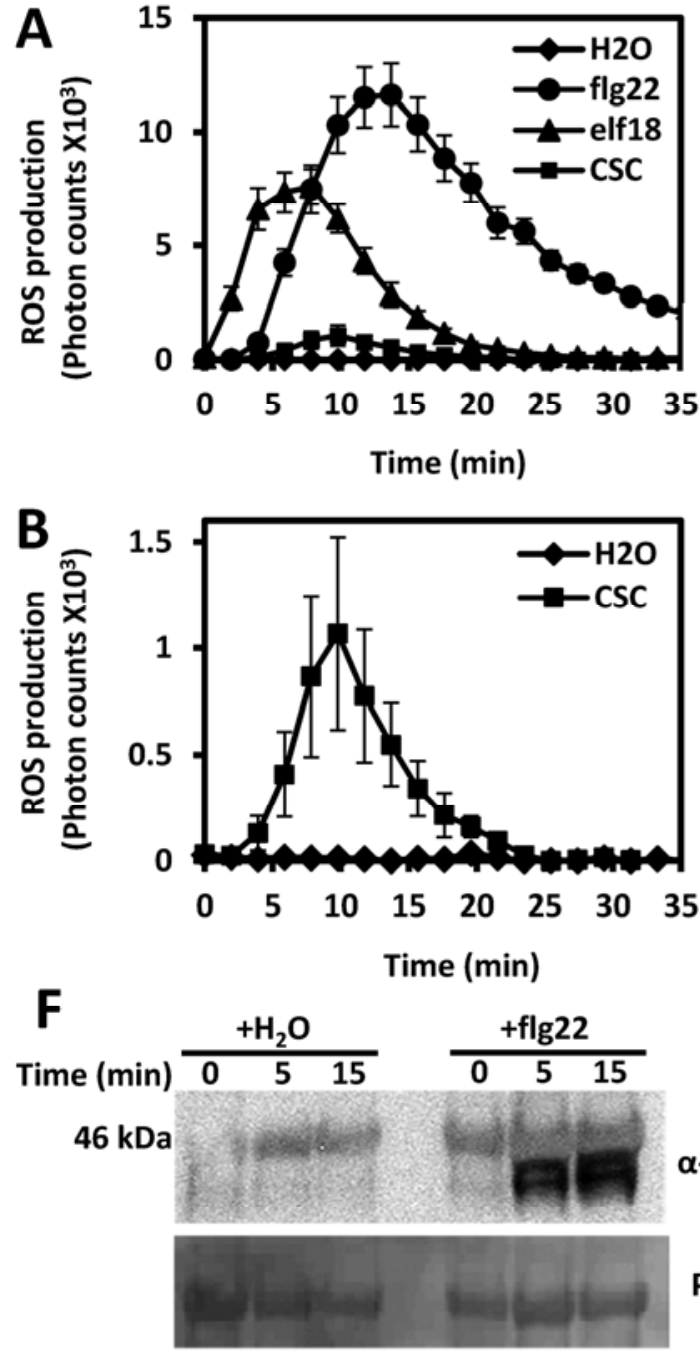

$\alpha$-pMAPK

Ponceau
(Fig. 1C, D, and E). CSC at $1 \mathrm{~g} /$ liter was the optimum dose, with a decrease in ROS with further increases in concentration (Fig. $1 \mathrm{E})$, which may be due to contaminants present in the crude preparation of chitin (derived from crab shells) used in this study. In all cases, $\mathrm{H}_{2} \mathrm{O}_{2}$ levels returned to background levels 30 to $45 \mathrm{~min}$ after PAMP treatment. The magnitude of the $B$. napus ROS burst in response to flg22 is approximately twothirds of the amplitude of the Col- 0 response to $100 \mathrm{nM}$ flg22 (Supplementary Fig. S1). The rapid and high-throughput nature of assessing the oxidative burst assay makes it very suitable for characterizing PAMP responsiveness in diverse accessions and in mapping populations.

MAPK cascades are the sequential phosphorylation of MAPK-kinase-kinases, MAPK-kinases, and, finally, MAPK (Tena et al. 2011). In A. thaliana, two distinct cascades are activated following flg22 treatment; namely, MEKKs-MKK4/5MPK3/6 and MEKK1-MKK1/2-MPK4/11 (Bethke et al. 2012; Tena et al. 2011). In B. napus, MAPK activation could be observed within 5 min of flg22 treatment compared with watertreated controls (Fig. 1F). The approximate sizes of the phosphorylated proteins correspond to MPK3 (44 kDa) and MPK6
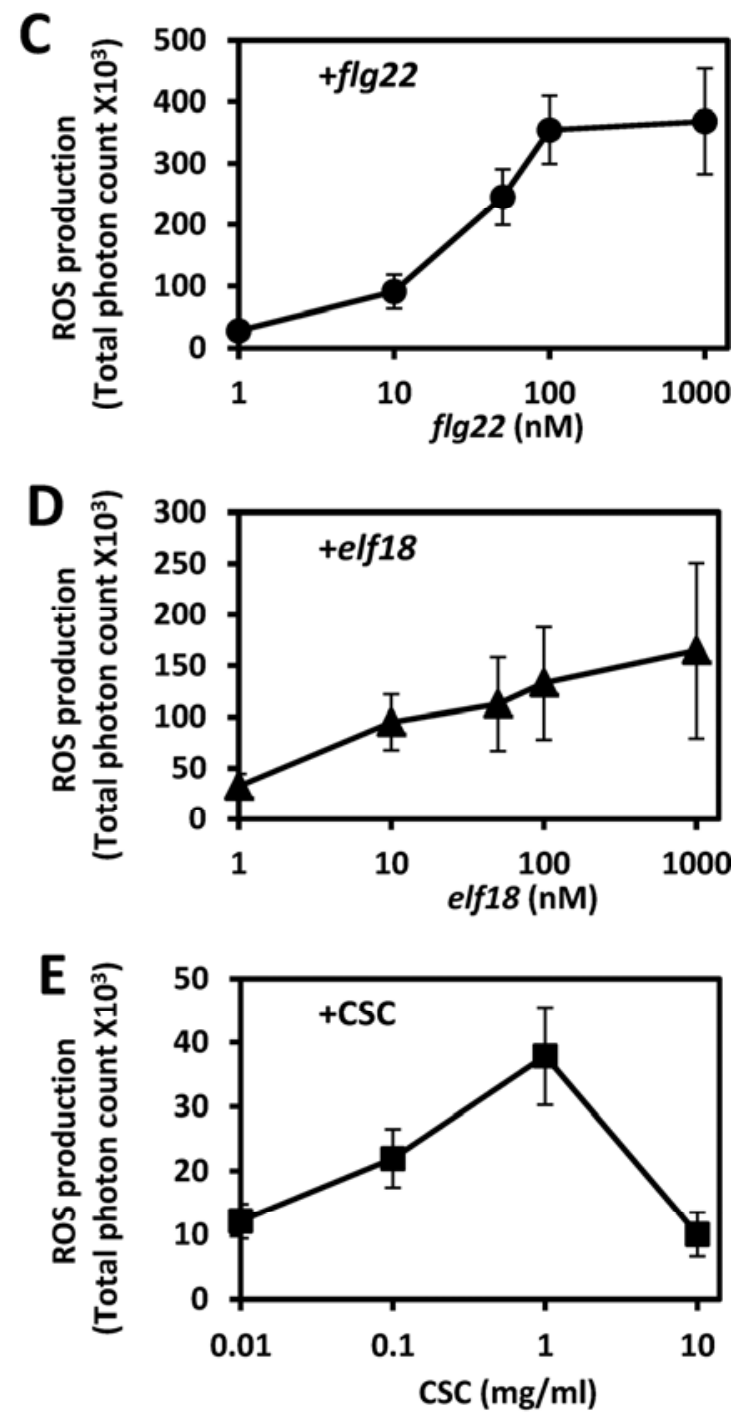

Fig. 1. Early pathogen-associated molecular pattern (PAMP)-induced events in Brassica napus 'Temple'. A, Oxidative burst in response to flg22 (100 nM), elf18 (100 nM), or crab shell chitin (CSC) (0.4 g/liter over $35 \mathrm{~min}$ following PAMP application. Error bars are the standard error of eight biological replicates. B, Oxidative burst in response to CSC (1 g/liter). $\mathbf{C}$ to $\mathbf{E}$, Dose response curves for flg22-, elf18-, and CSC-triggered reactive oxygen species (ROS) production over a 40-min time course following PAMP application. Error bars are the standard error of eight biological replicates. F, Mitogen-activated protein kinase (MAPK) activation following $1 \mu \mathrm{M}$ flg22 treatment in B. napus visualized with an immunoblot using a human anti-p42/44-ERK antibody. Lower panel: Ponceau stain of total proteins. 
(48 $\mathrm{kDa}$ ) in A. thaliana although, without further functional characterization of Brassica MAPK, their exact identities are still unknown.

\section{Transcriptional changes upon PAMP treatment.}

Two different approaches were used to identify PAMPresponsive $B$. napus genes that could be used as PTI markers. A first approach was to focus on Brassica genes previously reported as being induced during the interaction of $B$. napus with $S$. sclerotiorum at early time points after infection (Zhao et al. 2009), or on B. napus orthologs of $A$. thaliana genes upregulated upon treatment with flg22 (Zipfel et al. 2004). Of these, $B n M P K 3, B n M P K 4$, and BnWRKY33 were consistently upregulated upon flg22 and CSC treatment (Fig. 2A to C), making them effective markers for PAMP responses in future work. In a second approach, we investigated genome-wide changes in expression through Illumina sequencing of total RNA extracted from leaves treated for 0,1 , or $3 \mathrm{~h}$ with $100 \mathrm{nM}$ flg22. mRNA sequence reads were aligned to a $B$. napus unigene collection and quantified as the number of reads per kilobase per million mapped reads (RPKM) (Higgins et al. 2012). There were 59,118 unigenes in the A genome and 61,594 unigenes in the $\mathrm{C}$ genome, with sufficient expression ( $>0.002$ RPKM) at all three time points to be included in the analysis (Supplementary Table $\mathrm{S} 1$ ). Annotation of the B. napus unigenes was performed using BLASTN analysis of the unigene sequence against the TAIR 9 Arabidopsis genome database using an E-value threshold of 1E-30. Substantial changes in gene expression were observed after flg22 treatment (Supplementary Fig. S2); approximately $35 \%$ of B. napus genes were increased or decreased more than twofold after $3 \mathrm{~h}$ (Table 1). The list of flg22-regulated genes provides a valuable source of candidate marker genes for investigating PTI in Brassica spp.

A large number of genes that were twofold up- or downregulated were genome specific, with predicted homologous copies not being co-expressed together (Fig. 2D). This might be due to the higher false-positive rate at twofold expression changes. Most unigenes that were upregulated more than fourfold on PAMP treatment had an expression pattern similar to its orthologous copy, as can be seen in the highly significant correlation between $\mathrm{A}$ and $\mathrm{C}$ genome orthologous gene expression in Figure $2 \mathrm{E}$. There was a highly significant $(P<0.0001)$
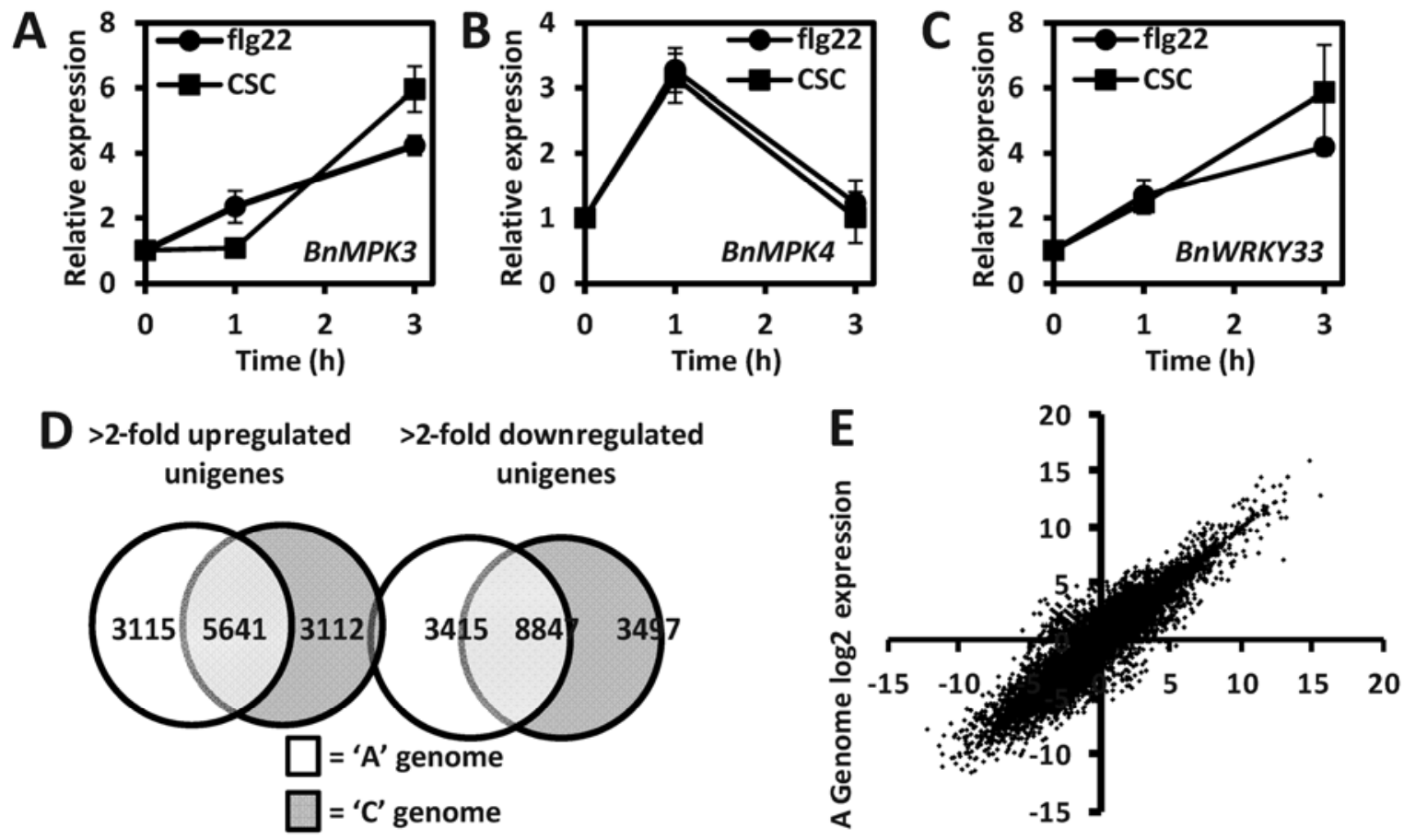

CGenome log2 expression

Fig. 2. Transcriptional changes in Brassica napus 'Temple' after pathogen-associated molecular pattern (PAMP) treatment. Expression of A, BnMPK3; B, BnMPK4; and C, BnWRKY33 after treatment with crab shell chitin (CSC) $(0.4 \mathrm{~g} /$ liter) or flg22 (100 nM) measured by quantitative reverse-transcriptase polymerase chain reaction. Transcript levels were normalized against EF1a expression. D, Up- and downregulated expression of homologous genes in the A and $\mathrm{C}$ genomes of $B$. napus after $100 \mathrm{nM}$ flg22 treatment. E, Correlation of homologous expression for every unigene found in both the $\mathrm{A}$ and $\mathrm{C}$ genomes.

Table 1. Genome-wide changes in gene expression after pathogen-associated molecular pattern (PAMP) treatment in the A and C genomes of Brassica napus $^{\mathrm{a}}$

\begin{tabular}{|c|c|c|c|c|c|c|}
\hline \multirow[b]{2}{*}{ Fold induction } & \multicolumn{2}{|c|}{ A genome } & \multicolumn{2}{|c|}{ C genome } & \multicolumn{2}{|c|}{ Overall } \\
\hline & T1/T0 & T3/T0 & T1/T0 & T3/T0 & T1/T0 & T3/T0 \\
\hline$>2$-fold up & $5,677(9.6 \%)$ & $8,756(14.8 \%)$ & $5,678(9.2 \%)$ & $8,763(14.2 \%)$ & $11,355(9.4 \%)$ & $17,519(14.5 \%)$ \\
\hline$>4$-fold up & $3,355(5.6 \%)$ & $5,074(8.6 \%)$ & $3,249(5.2 \%)$ & $5,106(8.3 \%)$ & $6,604(5.4 \%)$ & $10,180(8.4 \%)$ \\
\hline$>8$-fold up & $2,498(4.2 \%)$ & $3,659(6.2 \%)$ & $2,389(3.8 \%)$ & $3,641(5.9 \%)$ & $4,887(4 \%)$ & $7,580(6.2 \%)$ \\
\hline$<2$-fold down & $8,319(14 \%)$ & $12,257(20.1 \%)$ & $8,437(13.7 \%)$ & $12,339(20 \%)$ & $16,756(13.8 \%)$ & $24,596(20.4 \%)$ \\
\hline$<4$-fold down & $5,025(8.5 \%)$ & $9,039(15.3 \%)$ & $5,159(8.3 \%)$ & $9,116(14.8 \%)$ & $10,184(8.4 \%)$ & $18,155(15 \%)$ \\
\hline$<8$-fold down & $3,773(6.3 \%)$ & $6,891(11.6 \%)$ & $3,807(6.2 \%)$ & $6,875(11.6 \%)$ & $7,580(6.2 \%)$ & $13,766(11.4 \%)$ \\
\hline Total unigenes & \multicolumn{2}{|c|}{59,118} & \multicolumn{2}{|c|}{61,594} & \multicolumn{2}{|c|}{120,712} \\
\hline
\end{tabular}

${ }^{\text {a }}$ Gene expression at $0 \mathrm{~h}$ is compared with 1 and $3 \mathrm{~h}$. 
correlation between the expression of homologous genes between genomes (Fig. 2E).

Consistent with their phylogenetic relationship, the high degree of synteny with $A$. thaliana allows functional categorization of $B$. napus transcripts using the Mapman program (Thimm et al. 2004). Significant upregulation of LRR-RLK was observed, including most of family XII (Supplementary Fig. S3). Other notable clusters of upregulated genes correspond to WRKY transcription factors, enzymes involved in phenylpropanoid lignin and glucosinolate metabolic pathways, and a general downregulation of pathways involved in photosynthesis and starch production. The orthologs of the LRRRLK FLS2, EFR, and BAK1 as well as the LysM-RLP LYM2 and LysM-RLK CERK1 were all upregulated to a similar extent, whereas the LRR-RLK BRI1 (the brassinosteroid recep- tor) was not affected in its expression. Interestingly, approximately $10 \%$ of the genes showing greater than fivefold upregulation have no clear homology to A. thaliana genes.

\section{PAMP treatment induces structural defenses and inhibits seedling growth in B. napus.}

Later responses to PAMP treatment include cell wall reinforcement through callose deposition and lignification (Humphrey et al. 2007). To investigate callose deposition in B. napus, leaf tissue was stained with aniline blue $24 \mathrm{~h}$ after infiltration with $\mathrm{H}_{2} \mathrm{O}$, flg22, or CSC. We observed significantly more callose deposits after PAMP treatment than after water control (Fig. 3A and B). PAMP-induced lignification also occurred in B. napus, and this was more extensive after wounding (Fig. 3C). These results confirm that cell wall reinforcement through callose
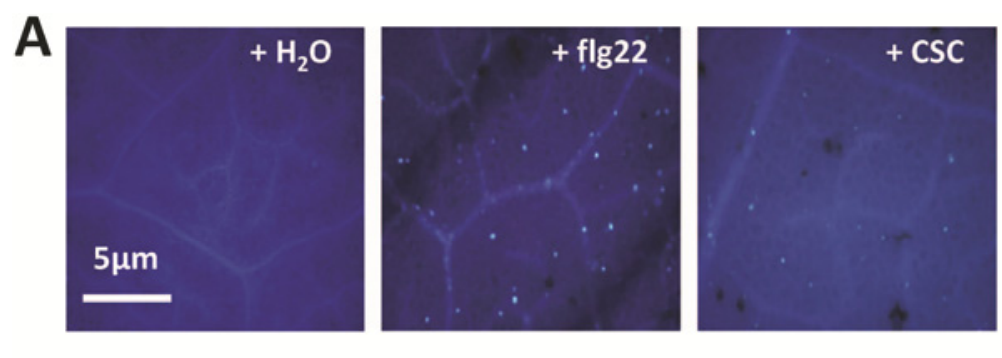

C
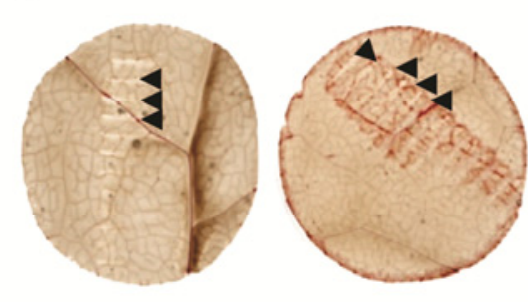

$+\mathrm{H}_{2} \mathrm{O}$

$+f \mid g 22$
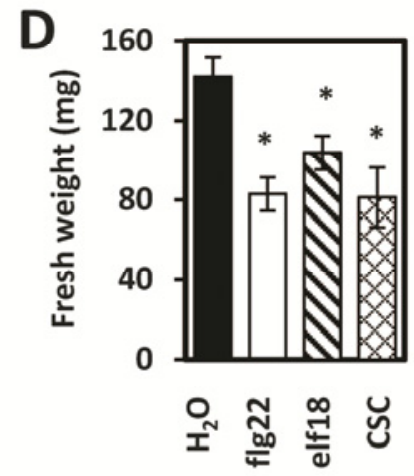

B
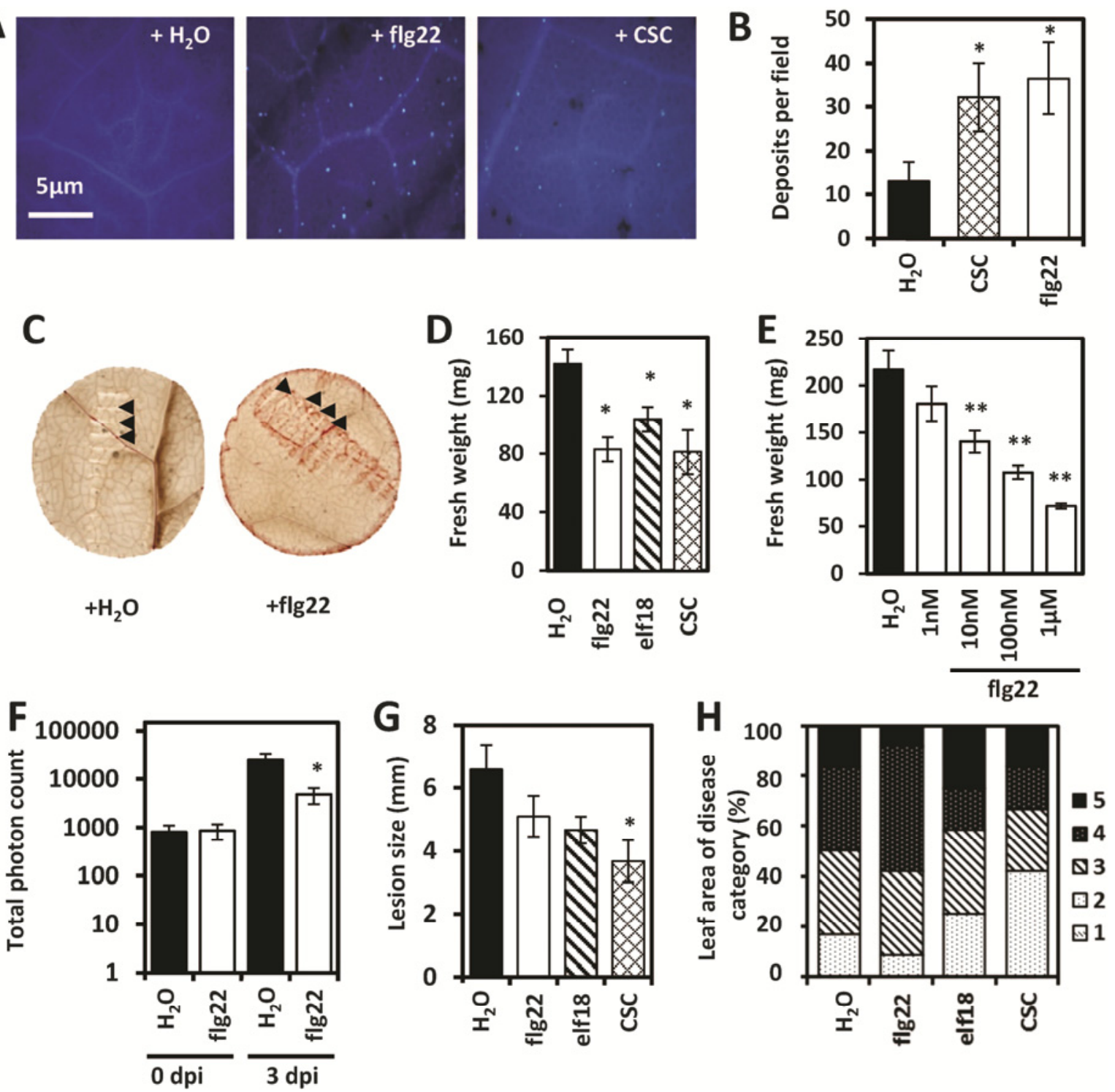

Fig. 3. Physiological changes upon pathogen-associated molecular pattern (PAMP) treatment in Brassica napus 'Temple'. A, Microscopic comparison of callose deposits after PAMP infiltration and staining with aniline blue. B, Total number of callose deposits per field of view. Error bars represent standard error of 10 biological replicates; * indicates $P<0.05$ ( $t$ test). C, Flg22 (100 nM) induces more lignification of wound sites after staining with phloroglucinol compared with treatment with $\mathrm{H}_{2} \mathrm{O}$. Wound sites are indicated by arrows. D, Seedling growth inhibition of $B$. napus in liquid Murashige-Skoog media containing $\mathrm{H}_{2} \mathrm{O}$, flg22 (100 nM), elf18 (100 nM), or crab shell chitin (CSC) (4 g/liter) 10 days after germination. E, Dose dependency of seedling growth inhibition. Error bars represent standard error of 12 biological replicates; ** indicates $P<0.01$ ( $t$ test). F, Growth of Pseudomonas syringae pv. tomato DC3000 $h r c C^{-}$luxCDABE after PAMP treatment by measuring total photons recorded over $5 \mathrm{~s}$ of sampling. G, The flg22 (100 nM), elf18 (100 nM), and CSC (1 g/liter) treatments reduce symptoms caused by Botrytis cinerea. H, Symptoms caused by Sclerotinia sclerotiorum were not reduced after infiltration with flg22 (100 nM), elf18 (100 nM), or CSC (1 g/liter). Scale: $1=$ no lesion, $2=$ no spreading lesion, $3=$ lesion $\leq 10 \mathrm{~mm}, 4=$ lesion $>10 \mathrm{~mm}$, and $5=1$ eaf disc fully consumed, with extensive aerial hyphae. 
induction and lignification can be readily induced and measured in B. napus.

PAMP application also inhibits $B$. napus seedling growth similarly to what has been previously observed in $A$. thaliana and other members of the Brassicaceae family (Dunning et al. 2007; Vetter et al. 2012). Significant growth inhibition can be seen in response to flg22, elf18, and CSC (Fig. 3D), and the effect is dose dependent (Fig. 3E). This high-throughput assay
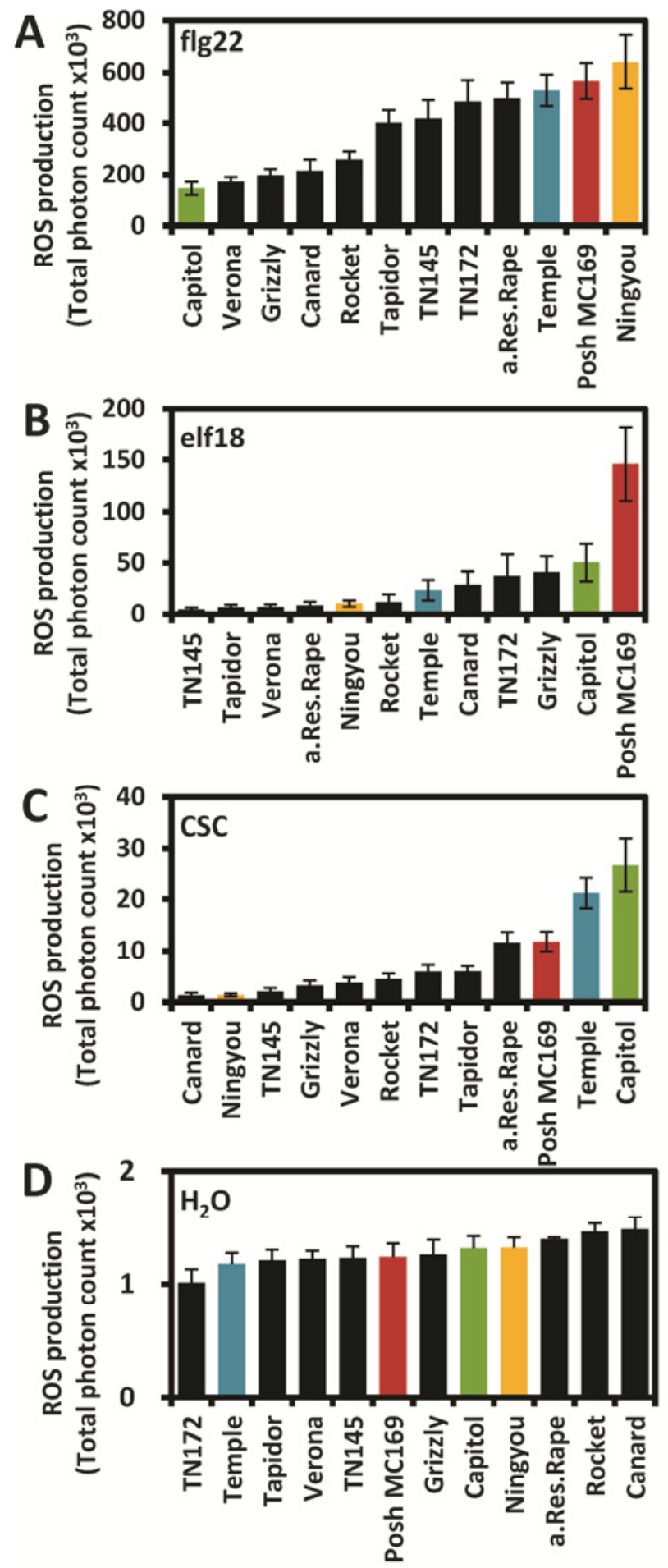

Fig. 4. Variation in pathogen-associated molecular pattern (PAMP) responses between Brassica napus cultivars. A to D, Oxidative burst in response to flg22 $(100 \mathrm{nM})$, elf18 $(100 \mathrm{nM})$, or crab shell chitin (CSC) (4 g/liter) or $\mathrm{H}_{2} \mathrm{O}$ treatment. Data are expressed as total photon counts over 40 min, with error bars representing the standard error of eight biological replicates. Cultivars discussed in the text are highlighted in color. E, Callose deposition in B. napus 'Temple' and 'POSH MC169' $24 \mathrm{~h}$ after infiltration with $\mathrm{H}_{2} \mathrm{O}$, flg22 (100 nM), or CSC (4 g/liter). Data shown are total number of callose deposits per field in Temple and POSH MC169. Error bars represent standard error of 10 biological replicates; * indicates $P<0.05$ ( $t$ test). F, Microscopic comparison of callose deposits after staining with aniline blue $24 \mathrm{~h}$ after PAMP treatment. could be readily applied to large-scale screens for quantifying PTI within Brassica populations.

PAMP treatment induces resistance to Brassica pathogens.

To assess the role of PAMP application in inducing disease resistance, we challenged $B$. napus tissue with PAMPs and measured the subsequent growth of pathogens. To avoid poten-
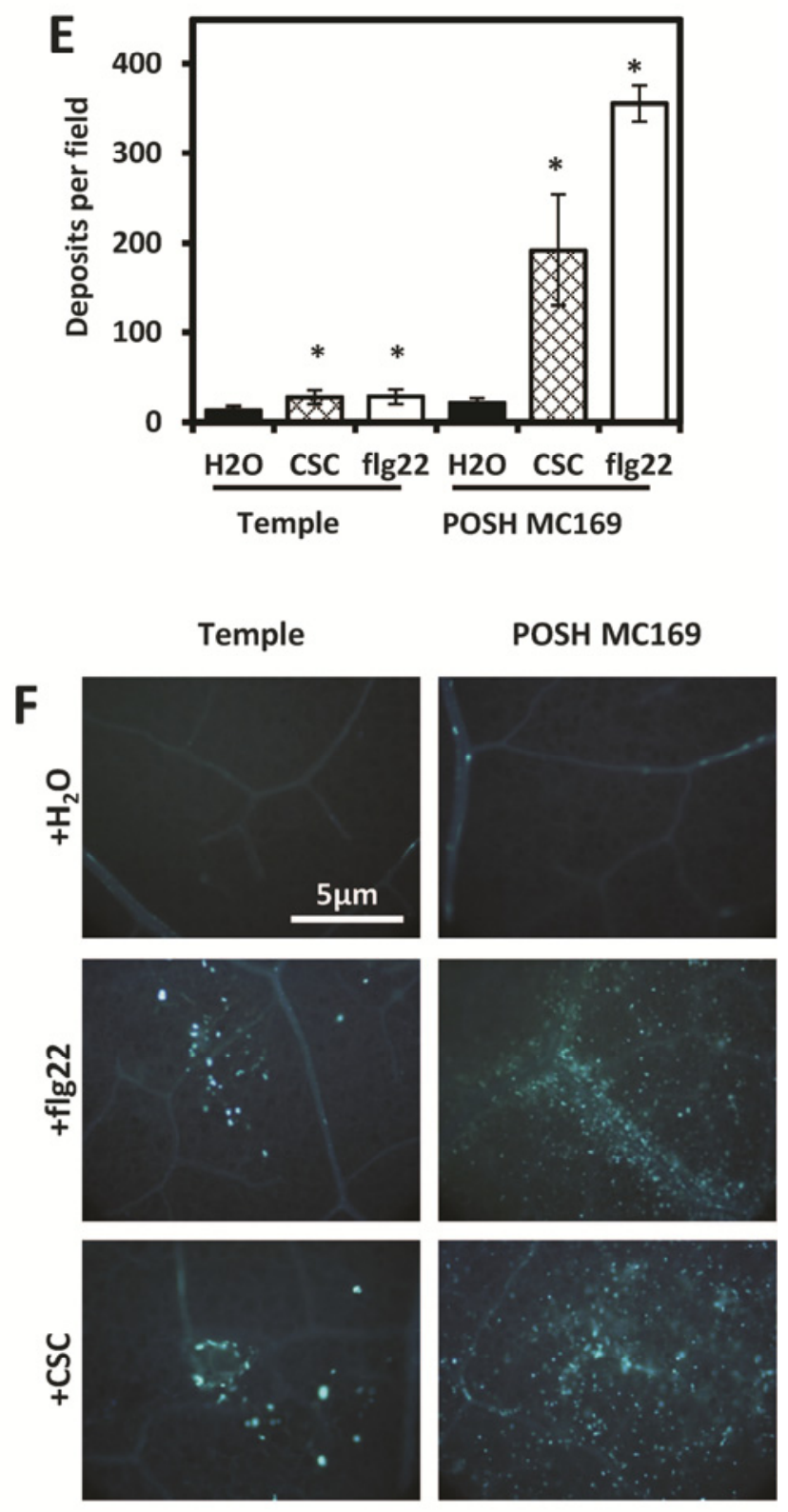

Vol. 27, No. 3, 2014 / 291 tial ETI responses in bacterial assays, we used a $P$. syringae 
pv. tomato DC3000 hrc $C^{-}$strain lacking a functional typethree secretion system. The $h r c C^{-}$strain was generated in a background that constitutively expresses the LUXCDABE operon $\left(L U X-h r c C^{-}\right)$, which has been used in high-throughput disease resistance screens in A. thaliana (Fan et al. 2008). Notably, we could observe a very clear correlation between the luminescence and bacterial number in $B$. napus leaves over a 3-day time-course following $L U X-h r c C^{-}$inoculation (Supplementary Fig. S4). We observed an approximately 50-fold increase in $L U X-h r c C^{-}$photon counts over 3 days, similar to that previously reported for the $h r c C^{-}$mutant on $A$. thaliana (Hauck et al. 2003). Growth was significantly reduced after $100 \mathrm{nM}$ flg22 treatment compared with the water-infiltrated control (Fig. 3F). We also measured consistent reduction in disease symptoms caused by $B$. cinerea after PAMP treatment, and this was always greatest after CSC application (Fig. 3G). However, no decrease in symptoms caused by $S$. sclerotiorum could be observed after PAMP treatment (Fig. 3H), which may be due to the hypervirulence of the strain used. In future work, it will be interesting to test whether PAMP treatment can affect disease caused by less virulent strains of $S$. sclerotiorum. Nevertheless, our results demonstrate that PIR provides a quantifiable measure of PTI in B. napus, which could be extended to screening with other PAMPs or pathogens.

\section{Significant variation in PAMP responses exists between $B$. napus cultivars.}

With a range of PTI assays in hand, we next wanted to measure the extent of natural variation in PAMP responses of $B$. napus cultivars present in the genetic diversity set OREGIN containing traits of interest to breeding programs. We found substantial variation between cultivars in the oxidative burst response to flg22, elf18, and CSC (Fig. 4A). Some cultivars such as 'POSH MC169' gave a consistently strong response to all three PAMPs (Fig. 4A to C, red bar). Notably, cultivars with a strong response to one PAMP did not necessarily give a strong response to other PAMPs. 'Ningyou', a cultivar very susceptible to L. maculans (Fitt et al. 2008), had a high response to flg22 and very low responses to elf18 and CSC (Fig. 4A to $\mathrm{C}$, yellow bar). In contrast, 'Capitol' responded strongly to elf18 and CSC but very weakly to flg22 (Fig. 4A to C, green bar). No significant variation was found in the background levels of $\mathrm{H}_{2} \mathrm{O}_{2}$ between accessions (Fig. 4D). To further explore variation in PTI response, callose deposition was compared, revealing a nearly 10-fold increase in the number of deposits seen after flg22 and CSC treatment in POSH MC169 compared with Temple (Fig. 4E and F). The very large difference in PAMP responses measured between B. napus cultivars indicates that PTI could readily be mapped to test associations with quantitative disease resistance. The identification of molecular markers associated with quantitative disease resistance would be of considerable benefit in B. napus breeding programs.

\section{MATERIALS AND METHODS}

All reagents used were from Sigma (Gillingham, Dorset, U.K.) unless stated otherwise.

\section{Plant material.}

B. napus plants were maintained in a lit glasshouse with a 16-h photoperiod and an average of 18 and $12^{\circ} \mathrm{C}$ day and night temperatures, respectively, and grown in a peat/sand (3:1) mix soil. Seed for all Brassica cultivars were provided by C. Morgan (John Innes Centre, Norwich, U.K.) and are described at the OREGIN diversity project website. Thetypical appearance of selected cultivars used in the study is shown in Supplementary Figure S5.
PAMP solutions.

Flg22 (QRLSTGSRINSAKDDAAGLQIA) and elf18 (AcSKEKFERTKPHVNVGTIG) peptides were ordered from Peptron (Daejeon, Korea) and resuspended in sterile $\mathrm{H}_{2} \mathrm{O}$. Peptides were divided between $1-\mathrm{mM}$ and $100-\mu \mathrm{M}$ aliquots and were stored at $-20^{\circ} \mathrm{C}$ before use. The CSC used was NA-COS-Y, provided by Yaizu Suisankagaku Industry CO (Yaizu, Japan). The CSC was dissolved in sterile $\mathrm{H}_{2} \mathrm{O}(10 \%$ [wt/vol] $)$ on a shaker overnight and autoclaved before being kept at $-20^{\circ} \mathrm{C}$.

\section{Measurement of ROS generation.}

ROS measurement was performed with a luminol/peroxidasebased assay essentially as described by Felix and associates (1999). Leaf discs (diameter $=4 \mathrm{~mm}$ ) were cut with a cork borer from 5-week-old B. napus plants and incubated in $200 \mu \mathrm{l}$ of sterile water in a 96-well plate for $24 \mathrm{~h}$. The water was drained and replaced by a solution containing $0.2 \mathrm{nM}$ luminol at $34 \mathrm{mg} /$ liter, horseradish peroxidase (HRP) at $20 \mathrm{mg} / \mathrm{liter}$, and the PAMP to be tested. The luminescence was recorded over a 40-min period using a Varioskan Flash plate reader (Thermo Fisher Scientific, Waltham, MA, U.S.A.) and displayed as the sum of photon counts over this period. Assays were repeated at least four times.

\section{MAPK phosphorylation.}

Fifteen discs from 5-week-old B. napus leaves for each treatment and time point were vacuum infiltrated with sterile water and incubated at room temperature. After $16 \mathrm{~h}, 100 \mathrm{nM}$ flg22 or water was added, and leaf samples taken at 0,5 , and 15 min after treatment and flash-frozen in liquid nitrogen. Frozen samples were kept on ice and ground using a TissueLyser LT (Qiagen, Basel,Switzerland), then thawed in Lacus buffer (50 mM TRIS-HCl [pH 7.5], $10 \mathrm{mM} \mathrm{MgCl}_{2}, 15 \mathrm{mM}$ EGTA, $100 \mathrm{mM} \mathrm{NaCl}, 2 \mathrm{mM}$ dithiothreitol, $1 \mathrm{mM}$ NaF, $1 \mathrm{mM}$ NaMO, $0.5 \mathrm{mM} \mathrm{NaVO}, 30 \mathrm{mM}$ b-glycero-phosphate, $0.1 \% \mathrm{NP}-40$ with $0.5 \mathrm{mM}$ phenylmethylsulfonyl fluoride $1 \%$ protease inhibitor cocktail, and $100 \mathrm{nM}$ Calyculin A) (LC Laboratories, Woburn, MA, U.S.A.) added immediately before use. The homogenates were centrifuged for $30 \mathrm{~min}$ at $16,000 \times g$ and filtered through Miracloth. Total protein levels were quantified by Bradford assay. Samples $(40 \mu \mathrm{g})$ were loaded in $3 \times$ LDS loading buffer (Invitrogen, Carlsbad, CA, U.S.A.), separated by sodium dodecyl sulfate-polyacrylamide gel electrophoresis on a $12 \%$ acrylamide gel (Invitrogen), and transferred to a nitrocellulose membrane with an Iblot transfer system (Invitrogen). Total protein was visualized by staining with Ponceau solution. The blot was blocked with $5 \%$ (wt/vol) bovine serum albumen (Sigma) in TBS-Tween $(0.1 \%)$ for $2 \mathrm{~h}$ before three washes in TBS-Tween $(0.1 \%)$. Phospho-p44/42 MAPK (Erk1/2) (Thr202/Tyr204) rabbit monoclonal antibodies (NEB, Ipswich, MA, U.S.A.) diluted 1:2000 in TBS were incubated overnight according to the manufacturer's protocol, followed by an anti-rabbit HRP-conjugated antibody (Sigma) for $2 \mathrm{~h}$. The blot was revealed with ECL Plus Western blotting detection system (GE Healthcare, Little Chalfont, Buckinghamshire, U.K.) with a 2-min exposure. The assay was repeated four times with similar results.

\section{RNA isolation and quantitative}

reverse-transcriptase polymerase chain reaction.

Leaf discs (diameter $=4 \mathrm{~mm}$ ) were vacuum infiltrated with $\mathrm{H}_{2} \mathrm{O}$ or PAMP solution and sampled at 0,1 , and $3 \mathrm{~h}$. RNA was extracted from homogenized tissue using a TissueLyser LT (Qiagen) and purified using an RNeasy plant mini-kit (Qiagen) according to the manufacturer's instructions and treated with Turbo DNA-free DNase (Ambion, Austin, TX, U.S.A.). cDNA was synthesized from $2 \mu \mathrm{g}$ of total RNA using Superscript III 
RT (Invitrogen). Quantitative reverse-transcriptase polymerase chain reaction (qRT-PCR) was performed using primers as listed (Supplementary Table S2) on a Chromo 4 qPCR machine (Bio-Rad, Hemel Hempstead, U.K.) with SYBR Green RT-PCR Master Mix (Sigma). Relative transcript levels were determined at each time point from cycle threshold (CT) values according to the $\triangle \mathrm{CT}$ method using EFla as a reference. Fold-induction was determined by comparing transcript levels in PAMP-treated samples with water-treated controls. The assay was repeated three times with similar results.

\section{Illumina-based RNAseq analysis.}

Total RNA for Illumina sequencing was extracted as above. The samples were composed of RNA pooled from eight different biological replicates per treatment and time point. The samples were analyzed by Glasgow Polynomics at the University of Glasgow, prepared according to Illumina TruSeq RNA Sample Preparation Guide using the Illumina TruSeq RNA sample preparation kit starting with $1 \mu \mathrm{g}$ of total RNA. For the library validation, the library concentration was measured with Qubit, followed by quality assessment with a Bioanalyser and library quantification with Kapa kit using an Optikon 2 RTPCR machine. The libraries were then sequenced on Illumina Genome Analyser IIx (GAIIx), and the raw fastq data files containing quality-passed 73-base-long reads were generated for each sample separately with CASAVA software. These were aligned with Maq v0.7.1 (Li et al. 2008) against a pseudo-reference sequence specially developed for $B$. napus as described by Higgins and associates (2012). This comprises two variants of approximately 90,000 Brassica unigenes representing the $\mathrm{A}$ and $\mathrm{C}$ genome homologs for each. The Maq pileup files were parsed to count aligned reads and calculate a normalized RPKM value for each unigene variant. Brassica unigenes were functionally annotated by programmatic reference to a precomputed BLASTN analysis versus the TAIR10 A. thaliana gene models. Any unigene with less than 0.02 RPKM at all time points and treatments was removed before further analysis. Fold expression data were calculated between 1 and $0 \mathrm{~h}$ and 3 and $0 \mathrm{~h}$, then converted to $\log 2$ expression. The unigene expression dataset annotated with TAIR9 AGI numbers was adapted for use in the Mapman program in the following ways. Only a single AGI number could be inputted into the program; therefore, redundancy (as a result of homologous copies of the gene in B. napus or false-positive BLASTN hits) was removed by including only the unigene with the highest basal expression at the 0 -h time point. Expression was converted to $\log 2$ reads per million and inputted into Mapman using the Arabidopsis accession number references as described by Thimm and associates (2004). Raw data were deposited in the EMBL short-read archive under accession number ERA248806.

\section{Callose deposition.}

Leaves were infiltrated with PAMP solution or $\mathrm{H}_{2} \mathrm{O}$ using a 1 -ml needleless syringe and discs (diameter $=4 \mathrm{~mm}$ ) were taken after $24 \mathrm{~h}$ from within the infiltrated zone but distal from the wounded inoculation site. The discs were cleared with $70 \%$ $\mathrm{EtOH}$ for $1 \mathrm{~h}, 95 \% \mathrm{EtOH}+0.5 \%$ chloroform for $16 \mathrm{~h}$, then $100 \% \mathrm{EtOH}$ for $2 \mathrm{~h}$, repeated until all chlorophyll was removed. The samples were rehydrated sequentially for $30 \mathrm{~min}$ each in $70 \% \mathrm{EtOH}, 50 \% \mathrm{EtOH}$, and $67 \mathrm{mM} \mathrm{K}_{2} \mathrm{HPO}_{4}$ at $\mathrm{pH} 11$. Callose was stained in a $0.01 \%(\mathrm{wt} / \mathrm{vol})$ aniline blue solution in $67 \mathrm{mM}$ $\mathrm{K}_{2} \mathrm{HPO}_{4}$ at $\mathrm{pH} 9.5$ for $1 \mathrm{~h}$. The leaf discs were mounted in a solution of $70 \%$ glycerol and $30 \%$ aniline blue and viewed under a Nikon Eclipse 800 microscope. Callose foci within the frame of a single image (magnification $\times 10$ ) were counted, and the assay was repeated four times with similar results.

\section{Lignin staining.}

Leaf discs $($ diameter $=10 \mathrm{~mm}$ ) were surface sterilized with $70 \% \mathrm{EtOH}$ and rinsed with $\mathrm{H}_{2} \mathrm{O}$ in sterile conditions. Each leaf disc was wounded using forceps and transferred to $30 \mathrm{ml}$ of $\mathrm{H}_{2} \mathrm{O}$ or PAMP solution overnight. Leaf discs cleared as described above were transferred to a $2 \%$ (wt/vol) phloroglucinol (Pomar et al. 2002) solution in $20 \% \mathrm{HCl}$. The stained leaf discs were photographed after $5 \mathrm{~min}$. The assay was repeated four times with similar results.

\section{Seedling growth inhibition.}

Seed were sterilized for 2 min in $3 \%$ bleach, then $70 \%$ ethanol, and washed three times in $\mathrm{H}_{2} \mathrm{O}$. Seed were pregerminated on $1 \%$ water agar for $48 \mathrm{~h}$ before transfer to $250-\mathrm{ml}$ glass beakers containing $200 \mathrm{ml}$ of liquid Murashige-Skoog media. PAMP solutions or water were added and the seed left shaking at $21^{\circ} \mathrm{C}$ with $12 \mathrm{~h}$ of light and $12 \mathrm{~h}$ of darkness. Fresh weight was recorded 10 days after transfer to liquid media. The assay was repeated four times with similar results.

\section{PIR.}

All PAMP pretreatments were made $24 \mathrm{~h}$ prior to pathogen challenge by vacuum-infiltration of leaf discs (diameter $=20$ $\mathrm{mm}$ ) with $100 \mathrm{nM}$ flg22 or elf $18, \mathrm{CSC}$ at $1 \mathrm{~g} / \mathrm{liter}$, or water and leaves were placed on water agar $(6 \mathrm{~g} / \mathrm{liter})$. $P$. syringae pv. tomato DC3000 hrc $C^{-}$luxCDABE (Fan et al. 2008) was kindly provided by J. Fan (John Innes Centre) and cultured on King's broth $(\mathrm{KB})$ agar with kanamycin at $25 \mathrm{~g} /$ liter and rifampicin at $50 \mathrm{~g} /$ liter for 2 days at $28^{\circ} \mathrm{C}$. A sample of the bacteria was transferred to liquid $\mathrm{KB}$ with the same antibiotics and incubated for $16 \mathrm{~h}$ at $200 \mathrm{rpm}$ and $28^{\circ} \mathrm{C}$. The bacterial solution was diluted to an optical density at $600 \mathrm{~nm}$ of 0.02 in $10 \mathrm{mM}$ $\mathrm{MgCl}_{2}$ and vacuum infiltrated into leaf discs. B. cinerea strain B05.10 was cultured on malt extract agar (Oxoid, Hampshire, U.K.) supplemented with yeast extract at 2 g/liter and extra agar at $5 \mathrm{~g} / \mathrm{liter}$, and spores were collected as described by Stefanato and associates (2009). A suspension of $2.5 \times 10^{6}$ spores/ml $(200 \mu \mathrm{l})$ was spread evenly on a fresh plate of onefifth potato dextrose agar (PDA) and incubated at $21^{\circ} \mathrm{C}$. Then, $24 \mathrm{~h}$ later, agar plugs (diameter $=4 \mathrm{~mm}$ ) from the colony were applied to the center of the infiltrated leaf discs, which were incubated under high humidity at $21^{\circ} \mathrm{Cm}$ and lesion size was recorded 3 days post inoculation.

S. sclerotiorum, isolated from pea plants in 2009, was provided by J. Thomas (National Institute of Agricultural Botany, Cambridge, U.K.), stored as dry sclerotia, and cultured on PDA at $21^{\circ} \mathrm{C}$. The disease assay was similar to $B$. cinerea, except that the one-fifth PDA plates were inoculated with agar plugs from an actively growing PDA plate and plugs for plant inoculation were cut from the growing edge of the colonies after 2 days. S. sclerotiorum infection was scored after 2 days using a scale of 1 to 5 according to disease severity.

\section{Statistical analysis.}

A $t$ test was used for the following comparisons: callose deposition for PAMP treatments compared with water, seedling growth inhibition of PAMP-treatments compared with water, and induced disease resistance for bacterial and $B$. cinerea assays. A $\chi^{2}$ test was performed on the PIR for the $S$. sclerotiorum assay.

\section{ACKNOWLEDGMENTS}

This work was funded by the Biotechnology and Biological Sciences Research Council (BBSRC) grants BB/G042960/1 (C. J. Ridout) and BB/G024936/1 (C. Zipfel) (as part of the consortium ERA-PG "PRRCROP") and BB/J004553/1 (C. J. Ridout), a BBSRC doctoral training 
grant to S. R. Lloyd, and the Gatsby Charitable Foundation (C. Zipfel). We thank P. Herzyk (Glasgow University, U.K.) for the Illumina sequencing, C. Morgan (The John Innes Centre, Norwich, U.K.) for providing Brassica seed, J. Fan and G. Creissen for providing the P. syringae pv. tomato DC3000 hrc $C^{-}$LUXABCDE strain, C. Ségonzac and F. Boutrot (The Sainsbury Laboratory, Norwich, U.K.) for technical assistance, and Yaizu Suisankagaku Industry CO (Yaizu, Japan) for providing CSC.

\section{LITERATURE CITED}

Albert, M. K., Jehle, A., Lipschis, M., Mueller, K., Zeng, Y., and Felix, G. 2010. Regulation of cell behaviour by plant receptor kinases: Pattern recognition receptors as prototypical models. Eur. J. Cell Biol. 89:200207.

Akimoto-Tomiyama, C., Sakata, K., Yazaki, J., Nakamura, K., Fujii, F., Shimbo, K., Yamamoto, K., Sasaki, T., Kishimoto, N., Kikuchi, S., Shibuya, N., and Minami, E. 2003. Rice gene expression in response to $\mathrm{N}$-acetylchitooligosaccharide elicitor: Comprehensive analysis by DNA microarray with randomly selected ESTs. Plant Mol. Biol. 52:537-551.

Aubertot, J. N., West, J. S., Bousset-Vaslin, L., Salam, M. U., Barbetti, M. J., and Diggle, A. J. 2006. Improved resistance management for durable disease control: A case study of phoma stem canker of oilseed rape (Brassica napus). Eur. J. Plant Pathol. 114:91-106.

Bethke, G., Pecher, P., Eschen-Lippold, L., Tsuda, K., Katagiri, F., Glazebrook, J., Scheel, D., and Lee, J. 2012. Activation of the Arabidopsis thaliana mitogen-activated protein kinase MPK11 by the flagellin-derived elicitor peptide, flg22. Mol. Plant-Microbe Interact. 25:471480.

Boller, T., and Felix, G. 2009. A renaissance of elicitors: Perception of microbe-associated molecular patterns and danger signals by patternrecognition receptors. Annu. Rev. Plant Biol. 60:379-406.

Chisholm, S. T., Coaker, G., Day, B., and Staskawicz, B. J. 2006. Hostmicrobe interactions: Shaping the evolution of the plant immune response. Cell 124:803-814.

de Jonge, R., van Esse, H. P., Maruthachalam, K., Bolton, M. D., Santhanam, P., Saber, M. K., Zhang, Z., Usami, T., Lievens, B., Subbarao, K. V., and Thomma, B. 2012. Tomato immune receptor Ve1 recognizes effector of multiple fungal pathogens uncovered by genome and RNA sequencing. Proc. Natl. Acad. Sci. U.S.A. 109:5110-5115.

Delourme, R., Chevre, A. M., Brun, H., Rouxel, T., Balesdent, M. H., Dias, J. S., Salisbury, P., Renard, M., and Rimmer, S. R. 2006. Major gene and polygenic resistance to Leptosphaeria maculans in oilseed rape (Brassica napus). Eur. J. Plant Pathol. 114:41-52.

Dodds, P. N., and Rathjen, J. P. 2010. Plant immunity: Towards an integrated view of plant-pathogen interactions. Nat. Rev. Genet. 11:539548.

Dubreuil-Maurizi, C., Trouvelot, S., Frettinger, P., Pugin, A., Wendehenne, D., and Poinssot, B. 2010. Beta-aminobutyric acid primes an NADPH oxidase-dependent reactive oxygen species production during grapevine-triggered immunity. Mol. Plant-Microbe Interact. 23:1012-1021.

Dunning, F. M., Sun, W., Jansen, K. L., Helft, L., and Bent, A. F. 2007. Identification and mutational analysis of Arabidopsis FLS2 leucine-rich repeat domain residues that contribute to flagellin perception. Plant Cell 19:3297-3313.

Fabro, G., Steinbrenner, J., Coates, M., Ishaque, N., Baxter, L., Studholme, D. J., Körner, E., Allen, R. L., Piquerez, S. J. M., Rougon-Cardoso, A., Greenshields, D., Lei, R., Badel, J. L., Caillaud, M.-C., Sohn, K.-H., Van den Ackerveken, G., Parker, J. E., Beynon, J., and Jones, J. D. G. 2011. Multiple candidate effectors from the oomycete pathogen Hyaloperonospora arabidopsidis suppress host plant immunity. PLoS Pathog. 7:e1002348. Published online.

Fan, J., Crooks, C., and Lamb, C. 2008. High-throughput quantitative luminescence assay of the growth in planta of Pseudomonas syringae chromosomally tagged with Photorhabdus luminescens luxCDABE. Plant J. 53:393-399.

Felix, G., Duran, J. D., Volko, S., and Boller, T. 1999. Plants have a sensitive perception system for the most conserved domain of bacterial flagellin. Plant J. 18:265-276.

Ferrari, S., Galletti, R., Denoux, C., De Lorenzo, G., Ausubel, F. M., and Dewdney, J. 2007. Resistance to Botrytis cinerea induced in Arabidopsis by elicitors is independent of salicylic acid, ethylene, or jasmonate signaling but requires PHYTOALEXIN DEFICIENT3. Plant Physiol. 144:367-379.

Fitt, B. D. L., Hu, B. C., Li, Z. Q., Liu, S. Y., Lange, R. M., Kharbanda, P. D., Butterworth, M. H., and White, R. P. 2008. Strategies to prevent spread of Leptosphaeria maculans (phoma stem canker) onto oilseed rape crops in China; costs and benefits. Plant Pathol. 57:652-664.

Fradin, E. F., Zhang, Z., Ayala, J. C. J., Castroverde, C. D. M., Nazar, R. N., Robb, J., Liu, C. M., and Thomma, B. P. H. J. 2009. Genetic dissec- tion of Verticillium wilt resistance mediated by tomato Ve1. Plant Physiol. 150:320-332.

Gomez-Gomez, L., and Boller, T. 2000. FLS2: An LRR receptor-like kinase involved in the perception of the bacterial elicitor flagellin in Arabidopsis. Mol. Cell 5:1003-1011.

Ham, J. H., Kim, M. G., Lee, S. Y., and Mackey, D. 2007. Layered basal defenses underlie non-host resistance of Arabidopsis to Pseudomonas syringae pv. phaseolicola. Plant J. 51:604-616.

Hann, D. R., and Rathjen, J. P. 2007. Early events in the pathogenicity of Pseudomonas syringae on Nicotiana benthamiana. Plant J. 49:607-618.

Hauck, P., Thilmony, R., and He, S. Y. 2003. A Pseudomonas syringae type III effector suppresses cell wall-based extracellular defense in susceptible Arabidopsis plants. Proc. Natl. Acad. Sci. U.S.A. 100:85778582

Higgins, J., Magusin, A., Trick, M., Fraser, F., and Bancroft, I. 2012. Use of mRNA-seq to discriminate contributions to the transcriptome from the constituent genomes of the polyploid crop species Brassica napus. BMC Genomics 13. Published online.

Huang, Y. J., Pirie, E. J., Evans, N., Delourme, R., King, G. J., and Fitt, B. D. L. 2009. Quantitative resistance to symptomless growth of Leptosphaeria maculans (phoma stem canker) in Brassica napus (oilseed rape). Plant Pathol. 58:314-323.

Humphrey, T. V., Bonetta, D. T., and Goring, D. R. 2007. Sentinels at the wall: Cell wall receptors and sensors. New Phytol. 176:7-21.

Iizasa, E., Mitsutomi, M., and Nagano, Y. 2010. Direct binding of a plant LysM receptor-like kinase, LysM RLK1/CERK1, to chitin in vitro. J. Biol. Chem. 285: 2996-3004.

Jones, J. D. G., and Dangl, J. L. 2006. The plant immune system. Nature 444:323-329.

Kaku, H., Nishizawa, Y., Ishii-Minami, N., Akimoto-Tomiyama, C., Dohmae, N., Takio, K., Minami, E., and Shibuya, N. 2006. Plant cells recognize chitin fragments for defense signaling through a plasma membrane receptor. Proc. Natl. Acad. Sci. U.S.A. 103:11086-11091.

Kishimoto, K., Kouzai, Y., Kaku, H., Shibuya, N., Minami, E., and Nishizawa, Y. 2010. Perception of the chitin oligosaccharides contributes to disease resistance to blast fungus Magnaporthe oryzae in rice. Plant J. 64:343-354.

Kuchitsu, K., Yazaki, Y., Sakano, K., and Shibuya, N. 1997. Transient cytoplasmic $\mathrm{pH}$ change and ion fluxes through the plasma membrane in suspension-cultured rice cells triggered by $N$-acetylchitooligosaccharide elicitor. Plant Cell Physiol. 38:1012-1018.

Kump, K. L., Bradbury, P. J., Wisser, R. J., Buckler, E. S., Belcher, A. R., Oropeza-Rosas, M. A., Zwonitzer, J. C., Kresovich, S., McMullen, M. D., Ware, D., Balint-Kurti, P. J., and Holland, J. B. 2011. Genome-wide association study of quantitative resistance to southern leaf blight in the maize nested association mapping population. Nat. Genet. 43:163-168.

Kunze, G., Zipfel, C., Robatzek, S., Niehaus, K., Boller, T., and Felix, G. 2004. The $\mathrm{N}$ terminus of bacterial elongation factor $\mathrm{Tu}$ elicits innate immunity in Arabidopsis plants. Plant Cell 16:3496-3507.

Lacombe, S., Rougon-Cardoso, A., Sherwood, E., Peeters, N., Dahlbeck, D., van Esse, H. P., Smoker, M., Rallapalli, G., Thomma, B. Staskawicz, B., Jones, J. D. G., and Zipfel, C. 2010. Interfamily transfer of a plant pattern-recognition receptor confers broad-spectrum bacterial resistance. Nat. Biotechnol. 28:365-U394.

Lee, S. W., Han, S. W., Sririyanum, M., Park, C. J., Seo, Y. S., and Ronald, P. C. 2009. A type I-secreted, sulfated peptide triggers XA21-mediated innate immunity. Science 326:850-853.

Li, H., Ruan, J., and Durbin, R. 2008. Mapping short DNA sequencing reads and calling variants using mapping quality scores. Genome Res. 18:1851-1858.

Liu, B., Li, J. F., Ao, Y., Qu, J. W., Li, Z. Q., Su, J. B., Zhang, Y., Liu, J., Feng, D. R., Qi, K. B., He, Y. M., Wang, J. F., and Wang, H. B. 2012a. Lysin motif-containing proteins LYP4 and LYP6 play dual roles in peptidoglycan and chitin perception in rice innate immunity. Plant Cell 24:3406-3419.

Liu, T. T., Liu, Z. X., Song, C. J., Hu, Y. F., Han, Z. F., She, J., Fan, F. F., Wang, J. W., Jin, C. W., Chang, J. B., Zhou, J. M., and Chai, J. J. 2012b. Chitin-induced dimerization activates a plant immune receptor. Science 336:1160-1164.

Medzhitov, R., and Janeway, C. A. 1997. Innate immunity: The virtues of a nonclonal system of recognition. Cell 91:295-298.

Mendes, B. M. J., Cardoso, S. C., Boscariol-Camargo, R. L., Cruz, R. B., Mourão Filho, F. A. A., and Bergamin Filho, A. 2010. Reduction in susceptibility to Xanthomonas axonopodis pv. citri in transgenic Citrus sinensis expressing the rice Xa21 gene. Plant Pathol. 59:68-75.

Miya, A., Albert, P., Shinya, T., Desaki, Y., Ichimura, K., Shirasu, K., Narusaka, Y., Kawakami, N., Kaku, H., and Shibuya, N. 2007. CERK1, a LysM receptor kinase, is essential for chitin elicitor signaling in Arabidopsis. Proc. Natl. Acad. Sci. U.S.A. 104:19613-19618.

Monaghan, J., and Zipfel, C. 2012. Plant pattern recognition receptor com- 
plexes at the plasma membrane. Curr. Opin. Plant Biol. 15:349-357.

Navarro, L., Zipfel, C., Rowland, O., Keller, I., Robatzek, S., Boller, T., and Jones, J. D. G. 2004. The transcriptional innate immune response to flg22. Interplay and overlap with Avr gene-dependent defense responses and bacterial pathogenesis. Plant Physiol. 135:1113-1128.

Nguyen, H. P., Chakravarthy, S., Velasquez, A. C., McLane, H. L., Zeng, L., Nakayashiki, H., Park, D.-H., Collmer, A., and Martin, G. B. 2010. Methods to study PAMP-triggered immunity using tomato and Nicotiana benthamiana. Mol. Plant-Microbe Interact. 23:991-999.

Ning, W., Chen, F., Mao, B., Li, Q., Liu, Z., Guo, Z., and He, Z. 2004 $\mathrm{N}$-acetylchitooligosaccharides elicit rice defence responses including hypersensitive response-like cell death, oxidative burst and defence gene expression. Physiol. Mol. Plant Pathol. 64:263-271.

Nishizawa, Y., Kawakami, A., Hibi, T., He, D.-Y., Shibuya, N., and Minami, E. 1999. Regulation of the chitinase gene expression in suspension-cultured rice cells by $\mathrm{N}$-acetylchitooligosaccharides: Differences in the signal transduction pathways leading to the activation of elicitor-responsive genes. Plant Mol. Biol. 39:907-914.

Petutschnig, E. K., Jones, A. M. E., Serazetdinova, L., Lipka, U., and Lipka, V. 2010. The lysin motif receptor-like kinase (LysM-RLK) CERK1 is a major chitin-binding protein in Arabidopsis thaliana and subject to chitin-induced phosphorylation. J. Biol. Chem. 285:28902 28911.

Pomar, F., Merino, F., and Barcelo, A.R. 2002. O-4-linked coniferyl and sinapyl aldehydes in lignifying cell walls are the main targets of the Wiesner (phloroglucinol-HCl) reaction. Protoplasma 220:17-28.

Proels, R. K., Oberhollenzer, K., Pathuri, I. P., Hensel, G., Kumlehn, J., and Hückelhoven, R. 2010. RBOHF2 of barley is required for normal development of penetration resistance to the parasitic fungus Blumeria graminis f. sp. hordei. Mol. Plant-Microbe Interact. 23:1143-1150.

Robatzek, S., Bittel, P., Chinchilla, D., Köchner, P., Felix, G., Shiu, S.-H., and Boller, T. 2007. Molecular identification and characterization of the tomato flagellin receptor LeFLS2, an orthologue of Arabidopsis FLS2 exhibiting characteristically different perception specificities. Plant Mol. Biol. 64:539-547.

Ron, M., and Avni, A. 2004. The receptor for the fungal elicitor ethyleneinducing xylanase is a member of a resistance-like gene family in tomato. Plant Cell 16:1604-1615.

Schwessinger, B., and Ronald, P. C. 2012. Plant innate immunity: Perception of conserved microbial signatures. Annu. Rev. Plant Biol. 63:451-482.

Shimizu, T., Nakano, T., Takamizawa, D., Desaki, Y., Ishii-Minami, N., Nishizawa, Y., Minami, E., Okada, K., Yamane, H., Kaku, H., and Shibuya, N. 2010. Two LysM receptor molecules, CEBiP and OsCERK1, cooperatively regulate chitin elicitor signaling in rice. Plant J. 64:204214.

Shinya, T., Motoyama, N., Ikeda, A., Wada, M., Kamiya, K., Hayafune, M., Kaku, H., and Shibuya, N. 2012. Functional characterization of CEBiP and CERK1 homologs in Arabidopsis and rice reveals the presence of different chitin receptor systems in plants. Plant Cell Physiol. 53:1696-1706.

Song, W.-Y., Wang, G.-L., Chen, L.-L., Kim, H.-S., Pi, L.-Y., Holsten, T., Gardner, J., Wang, B., Zhai, W.-X., Zhu, L.-H., Fauquet, C., and Ronald, P. 1995. A receptor kinase-like protein encoded by the rice disease resistance gene, Xa21. Science 270:1804-1806.

Sprague, S. J., Balesdent, M. H., Brun, H., Hayden, H. L., Marcroft, S. J., Pinochet, X., Rouxel, T., and Howlett, B. J. 2006. Major gene resistance in Brassica napus (oilseed rape) is overcome by changes in virulence of populations of Leptosphaeria maculans in France and Australia. Eur. J. Plant Pathol. 114:33-40.

Stefanato, F. L., Abou-Mansour, E., Buchala, A., Kretschmer, M., Mosbach, A., Hahn, M., Bochet, C. G., Métraux, J.-P., and Schoonbeek, H.-j. 2009. The ABC transporter BcatrB from Botrytis cinerea exports camalexin and is a virulence factor on Arabidopsis thaliana. Plant $\mathbf{J}$ 58:499-510.

Sun, W., Dunning, F. M., Pfund, C., Weingarten, R., and Bent, A. F. 2006 Within-species flagellin polymorphism in Xanthomonas campestris pv. campestris and its impact on elicitation of Arabidopsis FLAGELLIN SENSING2-dependent defenses. Plant Cell 18:764-779.

Takai, R., Isogai, A., Takayama, S., and Che, F.-S. 2008. Analysis of flagellin perception mediated by flg22 receptor OsFLS2 in rice. Mol. Plant-Microbe Interact. 21:1635-1642.

Tena, G., Boudsocq, M., and Sheen, J. 2011. Protein kinase signaling networks in plant innate immunity. Curr. Opin. Plant Biol. 14:519-529.

Thimm, O., Bläsing, O., Gibon, Y., Nagel, A., Meyer, S., Krüger, P. Selbig, J., Müller, L. A., Rhee, S. Y., and Stitt, M. 2004. Mapman: A user-driven tool to display genomics data sets onto diagrams of metabolic pathways and other biological processes. Plant J. 37:914-939.

Tronchet, M., Balagué, C., Kroj, T., Jouanin, L., and Roby, D. 2010. Cinnamyl alcohol dehydrogenases-C and D, key enzymes in lignin biosynthesis, play an essential role in disease resistance in Arabidopsis. Mol. Plant Pathol. 11:83-92.

Valdés-López, O., Thibivilliers, S., Qiu, J., Wenzhong Xu, W., Nguyen, T. H. N., Libault, M., Le, B. H., Goldberg, R. B., Hill, C. B., Hartman, G. L., Diers, B., and Stacey, G. 2011. Identification of quantitative trait loci controlling gene expression during the innate immunity response of soybean. Plant Physiol. 157:1975-1986.

Vanholme, R., Demedts, B., Morreel, K., Ralph, J., and Boerjan, W. 2010. Lignin biosynthesis and structure. Plant Physiol. 153:895-905.

Vetter, M. M., Kronholm, I., He, F., Haweker, H., Reymond, M., Bergelson, J., Robatzek, S., and de Meaux, J. 2012. Flagellin perception varies quantitatively in Arabidopsis thaliana and its relatives. Mol. Biol. Evol. 29:1655-1667.

Wan, J. R., Zhang, X. C., Neece, D., Ramonell, K. M., Clough, S., Kim, S. Y., Stacey, M. G., and Stacey, G. 2008. A LysM receptor-like kinase plays a critical role in chitin signaling and fungal resistance in Arabidopsis. Plant Cell 20:471-481.

Wan, J. R., Tanaka, K., Zhang, X. C., Son, G. H., Brechenmacher, L., Tran, H. N. N., and Stacey, G. 2012. LYK4, a lysin motif receptor-like kinase, is important for chitin signaling and plant innate immunity in Arabidopsis. Plant Physiol. 160:396-406.

Willmann, R., Lajunen, H. M., Erbs, G., Newman, M.-A., Kolb, D., Tsuda, K., Katagiri, F., Fliegmann, J., Bono, J.-J., Cullimore, J. V., Jehle, A. K., Götz, F., Kulik, A., Molinaro, A., Lipka, V., Gust, A. A., and Nürnberger, T. 2011. Arabidopsis lysin-motif proteins LYM1 LYM3 CERK1 mediate bacterial peptidoglycan sensing and immunity to bacterial infection. Proc. Natl. Acad. Sci. U.S.A. 108:19824-19829.

Yamada, A., Shibuya, N., Kodama, O., and Akatsuka, T. 1993. Induction of phytoalexin formation in suspension-cultured rice cells by $\mathrm{N}$-acetylchitooligosaccharides. Biosci. Biotechnol. Biochem. 57:405-409.

Yang, T. J., Kim, J. S., Kwon, S. J., Lim, K. B., Choi, B. S., Kim, J. A., Jin, M., Park, J. Y., Lim, M. H., Kim, H. I., Lim, Y. P., Kang, J. J., Hong, J. H., Kim, C. B., Bhak, J., Bancroft, I., and Parka, B. S. 2006. Sequence-level analysis of the diploidization process in the triplicated FLOWERING LOCUS C region of Brassica rapa. Plant Cell 18:13391347

Zhao, J., Buchwaldt, L., Rimmer, S. R., Sharpe, A., McGregor, L., Bekkaoui, D., and Hegedus, D. 2009. Patterns of differential gene expression in Brassica napus cultivars infected with Sclerotinia sclerotiorum. Mol. Plant Pathol. 10:635-649.

Zipfel, C., Robatzek, S., Navarro, L., Oakeley, E. J., Jones, J. D. G., Felix, G., and Boller, T. 2004. Bacterial disease resistance in Arabidopsis through flagellin perception. Nature 428:764-767.

Zipfel, C., Kunze, G., Chinchilla, D., Caniard, A., Jones, J. D. G., Boller, T., and Felix, G. 2006. Perception of the bacterial PAMP EF-Tu by the receptor EFR restricts Agrobacterium-mediated transformation. Cell 125:749-760.

\section{AUTHOR-RECOMMENDED INTERNET RESOURCE}

The Oilseed Rape Genetic Improvement Network (OREGIN) website: www.oregin.info 